\title{
Judicial Review of Criminal Code Articles on Adultery, Rape and Same-Sex Obscene in Indonesia Constitutional Court
}

\author{
Qurrata Ayuni \\ Universitas Indonesia, \\ Depok, Indonesia \\ qurrataayuni@ui.ac.id
}

\begin{abstract}
Through the case number 46 / PUU-XI / 2016, a number of Petitioners requested the Constitutional Court to expand the definition of adultery, rape and same-sex obscene in the Indonesia Criminal Code. In accordance with the Article $24 \mathrm{C}$ of the 1945 Constitution, the Constitutional Court is authorized to examine the law against the 1945 Constitution which is known as judicial review or constitutional review. The petitioners argue that the definitions of adultery, rape and same-sex obscene are no longer relevant to the problem in the society which resulting in various moral crises such as free sex and LGBT (Lesbian, Gay, Bisexual, and Transgender). On the other hand, this request is also opposed by some who claim that state intervention in private affairs is a violation of human rights. This discussion becomes interesting to be studied in relation to the role of the state in realizing a civil society in accordance with Pancasila and the 1945 Constitution. Using a juridical normative study, this paper will discuss debates and legal analysis through the point of view of human rights and constitutional law. At the end, this paper tries to examine the boundaries of freedom and the power of government to limit it in a plural society.
\end{abstract}

Keywords-Judicial Review; Human Rights; Criminal Code;

\section{INTRODUCTION}

It seems that the case No. 46 / PUU-XI / 2016 on the judicial review of the Criminal Code is one of the most complicated cases ever in the Constitutional Court. Since the first trial was held on $7^{\text {th }}$ of June 2016, the case has been through 19 trials and had not been decided until more than a year later. There are important constitutional debates to be answered; to what extent is the rights of privacy can be regulated in criminal law? And will the Constitutional Court give legality or prohibition of homosexual behavior in Indonesia?

There are 12 Indonesian citizens who appealed to the Constitutional Court to extend the meaning of adultery, rape and same-sex obscene in the Articles 284, 285 and 292 of the Indonesia Criminal Code (Kitab Undang-Undang Hukum Pidana or KUHP). The Article 284 of the Criminal Code essentially states that those who can be punished for adultery are intercourse between married people and others. This Article does not impose penalties for sexual acts committed against unmarried persons. The Petitioner argues that free sex behavior for single persons should be prohibited by criminal law because it is contrary to the cultural and religious values adopted in Indonesia. In addition, the absence of a free sex ban has been the source of various problems such as HIV / AIDS, abortion and other social problems in the community.

Another article which is also under review is Article 285 of the Criminal Code which regulates the rape. The definition of rape in Article 285 of the Criminal Code is only limited to the action, which is perpetrated by a male actor(s) to the female victim(s). Whereas according to the Petitioner that definition raises the potential for discrimination against men who were raped by women. Therefore, the Petitioner asked the Constitutional Court to expand the concept of rape not only men against women but also can be applied to women who raped men.

The Article 292 of the Criminal Code, which regulates the prohibition of obscene or same-sex obscene between adults to children, is the last article to be petitioned in this case. The Petitioner requests the Constitutional Court to expand the subject of such offense to anyone who performs same-sex obscene, hence any obscene behavior among adults such as; the sexual activity of Lesbian, Gay, Bisexual and Transgender (LGBT) can be punished under the Indonesian criminal law.

At the national level, the process of judicial review has raised conflicting arguments among the public, which become a shaper. Due to the sensitive issue behind the petition, several community groups and non-government organizations have shown their own respective point of views in this case. The main points, which are highly discussed, are related to the Article 284 and 292 of the Criminal Code. According to the opponent of the Petitioners, a request is a form of discrimination against minority sexual groups such as LGBT. While the request for the expansion of the definition of adultery in the Article 284 of the Criminal Code in the 
opponent's opinion is a form of over-criminalization for an act which should be considered as personal privacy rights.

In accordance with the Article $24 \mathrm{C}$ of the 1945 Constitution, the Constitutional Court has the authority to examine the constitutionality of a norm in the law. Therefore, the Constitutional Court may abolish a word, phrase and even the whole law if any of them is considered as a contradictory to the norm of the constitution. The petitioners' action should be seen as an act of responsible citizens, as they push their agenda through the corridor of constitution and law because the Constitutional Court has the constitutional mandate to determine the constitutionality of the norms of adultery, rape and same-sex obscene in Indonesia. To deliver the mandate, the Constitutional Court should respond to the petition through a lengthy process, which includes the debates on philosophical, sociological and juridical aspects of the law.

\section{CONTRACT To Right To Privacy?}

One of the opponent's arguments against the judicial review is that having sexual intercourse and performing samesex obscene are considered as essential parts of individual rights to privacy. Concisely, right to privacy can be interpreted as the right of everyone to protect the aspects of his life to be accessed and used by others (Donald M. Gillmor, et. al, 1990). Initially, the right to privacy is put forward by Samuel D. Warren and Louis D. Brandeis (1890) who assess the importance of protecting one's reputation against one's own life. This right to privacy concerns the right not to be publicized to the public.

The development of the right to privacy then evolves with the times; right to privacy is also applied to sexual orientation and choice of belief or religion (Sandra S. Klein, 1994). For this particular group, right to privacy is regarded as fundamental right for everyone. This right denotes the autonomy and the body integrity as well as personal identity relating to gender and sexuality. So that sexual activity should also fall within the category of personal affairs of a person that must be protected by the state. Likewise, with the identity of sexual orientation for the LGBT group which, according to them, must also be protected constitutionally.

This right to privacy is then associated with the Article 28G Paragraph (1) of the 1945 Constitution which guarantees personal protection and a sense of security to do or not to do something. Therefore, the state is deemed to discriminate a person for the sexual activity of mutual consent and sexual orientation, which is the right of one's privacy. So, they argue that the issue should not be defined as a crime on the Indonesian criminal code.

The right to privacy has a basic idea that places humans as the autonomous subject of themselves. The right to privacy gives the individual the right to isolate himself by getting out of public life and staying into his deepest private space, and to nurture himself according to his wishes and desires. The right also protects the actions of individuals as long as they do not interfere and endanger the others' privacy. Thus, the right to privacy protects the individual's autonomous space for his own existence and actions as long as it does not touch the liberty of others. The idea behind this argument is there is a specially protected space, which guarantees the individual existence, which does not violate the liberty of others.

The right to privacy is also associated with the Article 17 of the International Covenant on Civil and Political Rights (ICCPR), which states the prohibition against arbitrary interference with personal, family, home and correspondence issues to violate honor and reputation. Based on this argument, the opponent of the petition argues that a judicial review is an act which gives way to further the discrimination of vulnerable and minority groups, such as groups which have different sexual orientation especially those which advocate LGBT causes.

The crucial part of the debates on the right to privacy is the determination of the limits on which the state can actually enter the private lives of citizens. As the holder of sovereignty granted by the people as formulated in the Indonesian constitution, the state shall endeavor to provide the maximum protection for the citizens. These safeguards can be realized through legal instruments such as law and regulation.

For the Petitioners, the determination of the right to privacy which is part of state-guaranteed Human Rights may actually be restricted by law. The Petitioner argues the restrictions on right to privacy are constitutionally related to the Article 28J of the 1945 Constitution. As it is clearly mentioned on the Article 28J of the 1945 Constitution, in exercising their rights and freedoms, the people in Indonesia are obliged to respect and follow the limitations of rights and freedoms which is still in accordance with moral, religious, security and public order norm in Indonesia.

The Petitioner states that Indonesia is a religious state as mentioned in the first point of Pancasila. According to Tahir Azhary (2004), the basic concept of Indonesia as a legal state is different with the concept of rule of law, rechstaat and the socialist. He states that Indonesia has a distinctive concept of state law that is the state of Pancasila law which has a strong religious characteristic. Another feature is that the concept of the Pancasila state rests on the values of "Belief in the Almighty", the existence of religious freedom in a positive sense, atheism is not justified and the principles of kinship and harmony.

The Petitioner believes that the existence of arrangements in the Criminal Code, which are inconsistent with the moral and religious values living in Indonesia, is a form of contradiction to the Pancasila. This is based on the first principle of Indonesia which acknowledges the divinity of the Almighty as one of the foundations of the state of Indonesia. This basic concept is also clearly mentioned in Indonesian preamble of the constitution, which states that the Independence of Indonesia had been achieved by the grace of the Almighty and the high will of the people. Affirmation of the role of religion as the basis of the state is also stated in Chapter XI on Religion Article 29 paragraph (1) of the 1945 Constitution. Therefore, religious values shall be considered as a fundamental foundation not only in the socio-cultural context but also in the law and state governance in Indonesia. 


\section{UNIVERSAL AND PARTICULAR OF THE HuMAN Rights}

The ensuing debate over the right to privacy as part of human rights should not be diverted to the discussion on the universalism of human rights versus particular human rights. This discourse will lead to the question, is human rights known today is an absolute value?

One of the experts from related parties namely Dr. Atip Latipulhayat discussed these universal human rights in the Constitutional Court session. He said that everyone agrees that Human Rights are the inherent right of a man as given by the God Almighty and an inseparable part of man. Human rights given are actually religious teachings and values of the fundamental wisdom of nations that are the main source of human rights norms. The birth of modern human rights, among others, is marked by the formation of international legal instruments on human rights, especially after the Second World War primarily due to imperialism and colonialism whose substance is nothing but dehumanization. Imperialism and colonialism have buried human rights. In this sense, human rights context must be understood as processes and efforts to humanize humanity.

However, there is a debate over the use of human rights instruments as part of universal values nowadays. There are many opinions that claim human rights that currently exist to become a dominance of western culture to other cultures in the world. Human rights born in western concepts have been directed to be patrons of the ideal human rights practice. Even though this is not necessarily suitable for other countries that have cultural roots that are different from the roots of western culture.

Kris Wijoyo Soepandji (2017) even considered that there is a tendency to use western human rights as a new form of imperialism for developing countries. The birth of modern human rights, which was started by the formation of international legal instruments, especially after the Second World War actually happened due to the failure of western imperialism and colonialism to sustain their inhumane profitmaking system, so they need to make them look more humane. By understanding the process of that particular historical context we actually can understand that forcing the western human rights values blindly are only the tools of domination in other way to the newly independent nations such as Indonesia and the others, because Sukarno said the main modus operandi of imperialism is to make sure the object of the domination has the feeling of not being civilized (Kris Wijoyo Soepandji, 2017).

So, it is important for countries to understand the concept of universalism and particularism of human rights. In this case, the application of international instrument related human rights needs to be put in proportional worldview as the common values and principles. The Universal Declaration of Human Rights (UDHR), which is considered as a legal instrument that affirms the universalism of human rights actually reinforces the view that universalism of human rights, is more on the level of values and principles. The universalism of human rights contains the acknowledgment of human rights values and principles. UDHR is intended as standard-setting and implementation which can be used as a model for the formation of the constitution or other national legislation (Makau Mutua, 2016). It is a packaging in the form of the Declaration through the instrument of United Nations General Assembly Resolution rather than an international treaty implies an implicit understanding and recognition of the existence of particular values.

This distinction between the concept of universalism and particularism of human rights has actually come to an end since the signing of the 1993 Vienna Declaration, which states that there is recognition of the existence of regional minimum standards. The Declaration also states that the application of human rights universalism must take into account the special conditions of each country that has cultural, religious, social, economic and political diversity (Anush Hayrapetyan, 2010). Manfred Nowak (2004) mentions the doctrine that the application of human rights can be exercised in a margin of appreciation. The doctrine used in the European Court of Human Rights (ECHR) provides freedom for states to grant freedom in the application of human rights with the acknowledge of heterogeneous cultural, social, economic and political heterogeneity in each country (Alain Zysset, 2016).

For the adherents of absolute universalist human rights, particular values do not only impede the implementation of human rights but are also considered to be absent in the name of particular values, whether derived from religious teachings or the wisdom and values of a nation. Therefore, the judgment that the application of human rights should always be based on the application of human rights in the west is false thinking. Furthermore, the assumption that western human rights are the world's best practice might be seen what Sundaramoorthy (2016) says as western cultural imperialism. Therefore, it is important for Indonesia to understand that the western practice and principles of human rights need to be adopted wisely to be used in accordance with the values that exist in Indonesia.

Moreover, Dr. Atip Latipulhayat mentions that any law, which accommodates LGBT interests should be based on the characteristics of any particular states which are impossible to be forced to any state which already has their own deep-rooted values. The practice of LGBT recognition in Europe also varies. Even the European Court of Human Rights until now has never given the certainty that the right to such marriage is a universal right. In this case, Freeman says that rights must be understood within their cultural context. They should not be subsumed in other cultural practices. It is to be expected, nevertheless, that even universal human rights may be some defensible local qualification (Kirmayer, L.J., 2012).

\section{CONCLUSIONS}

The debate over the examination of the Articles 284, 285 and 292 of the Indonesian Criminal Code gives rise to a number of constitutional debates about how human rights applied in Indonesia. One party stated that right to privacy is a right that should not be ignored by the state because it will lead to discrimination and criminalization of vulnerable groups such as LGBT groups. In addition, the assumptions that the state potentially violates the right to privacy because it 
has gone too far to regulate the issue of free sex activity which is essentially a private right.

However, through the study of the concept of human rights and fundamentalism presented by Dr. Atip Latipulhayat found that principally the application of human rights in a country must be adapted to its culture and particular values. Through margin of appreciation, the freedom for countries to implement human rights is part of a doctrine known in international law. Therefore, in essence, the decision-making process in the Constitutional Court is not necessary to use human rights standards that apply in another state but important to use the values embraced in culture, religion and the constitution in Indonesia.

\section{ACKNOWLEDGEMENTS}

Thank you for the help of Kris Wijoyo Soepandji for discussing and editing this paper. I really appreciate it.

\section{REFERENCES}

[1] Alain Zyseet. (2016). The ECHR And Human Rights Theory: Reconciling The Moral and The Political Conceptions. London: Routledge.

[2] Anush Hayrapetyan. (2010). State Sovereignty and International Human Rights Vienna Declaration and the Program of Action. Retrieved from http://www.atlantic-community.org.

[3] Donald M. Gillmor, Et. All. (1990). Mass Communication Law $\left(5^{\text {th }}\right.$ Ed, p. 683-904). United State: West Pub. Co.

[4] Kirmayer, L.J. (2012). Culture and Context in Human Rights. In M. Dudley, D. Silove and F.Gale (Eds.), Mental Health and Human Rights: Vision, Praxis, and Courage (pp. 95-112). Oxford: Oxford University Press.

[5] Kris Wijoyo Soepandji. (2017). Ilmu Negara Prespektif Geopolitik Masa Kini. Depok: Badan Penerbit Fakultas Hukum Universitas Indonesia.

[6] Lakshini Sundaramoorthy. (2016). Is the idea of human rights a universal concept?, Merici — (Volume 2, p. 25). Ursula Hall Academic Journal. Australia: Australian Nasional University Press.

[7] Makau Mutua. (2016). Human Rights Standards: Hegemony, Law and politics. Suny Series, James N. Rosenau Series in Global Politics.

[8] Manfred Nowak. (2004). Introduction to The International Human Rights Regime. Raoul Wallenberg Institute Human Rights Library. Leiden: Martinus Hijhoff Publisher.

[9] Samuel D. Warren and Louis D. Brandeis. (1890). The Right to Privacy. Harvard Law Review (Vol.4, No.5). The Harvard Law Review Association. Pp 193-220.

[10] Sandra S. Klein. (1994). Sexual Freedom and Your Right to Privacy: A Selective Bibliography. Legal Reference v Services Quarterly, (Vol. 13(4)). The Haworth Press. pp. 112-124.

[11] Tahir Azhary. (2004). Negara Hukum: Suatu Studi Tentang PrinsipPrinsipnya dilihat dari Segi Hukum Islam. Jakarta : Kencana Press. 